\title{
ON THE POLYMORPHISM OF CYANOGENESIS IN LOTUS CORNICULATUS L.
}

\author{
VII. THE DISTRIBUTION OF THE CYANOGENIC FORM IN WESTERN \\ EUROPE
}

DAVID A. JONES

Unit of Genetics, University of Hull, Hull HU6 7RX, England

Received 27.ix.76

\begin{abstract}
SUMMARY
Samples of mature plants of Lotus corniculatus collected in natural habitats in western Europe show that the polymorphism for cyanogenesis in this species is not directly comparable with that in Trifolium repens. There is, however, a decline in the frequency of the cyanogenic form from the Netherlands to Scandinavia. It is argued that $T$. repens is not a satisfactory plant for studies of localised variation because of its widespread use in agriculture. Cyanogenic cultivated varieties of $L$. corniculatus are now regular contaminants of the grass seed sown on the edges of many new roads and consequently care must also be exercised when working with this species. Because L. corniculatus reproduces vegetatively the criteria used for sampling and estimating phenotype frequencies are discussed in detail. Some plants have the ability to change phenotype during the year and the problems this poses for population studies are explained.

Because there is no single explanation for the many examples of localised variation in the frequency of cyanogenic $L$. corniculatus it is argued that there is little purpose in continuing work whose principal objective is an overall hypothesis.
\end{abstract}

\section{INTRODUCTION}

IN a series of papers on Trifolium repens L., Daday (1954a, b, 1958, 1965) has presented evidence showing a relationship between the mean January temperature (Northern Hemisphere) and the frequency of the cyanogenic form in different populations. The technique of sampling which Daday used was as follows. He obtained seed through the co-operation of people all over the world, but he specified " 20 wild $T$. repens seed heads to be collected from five different ecological areas around the named locality or ' collection centre '; the collection to be of wild T. repens only, and the place of collection to be well isolated from any cultivated land or reseeded pasture".

A major disadvantage of the technique of sampling used by Daday is that local variation will be confounded when collections are made from five different ecological areas. Indeed, sampling established plants of $\mathcal{T}$. repens has readily revealed localisations in the distribution of the cyanogenic form (Jones, 1968). I have also obtained evidence showing that differences in the frequencies of the cyanogenic forms of Lotus corniculatus L. can occur over distances of no more than a few metres (Jones, 1972).

When the plant being studied is a perennial there is the choice of collecting seeds, seedlings or plants, representing the potential, the viable and the established components of a population. Although seeds and 
seedlings can give some indication of the genetic potential of a population, it is the mature plants which have withstood the rigours of establishment and survival, and will be the progenitors of future generations. There can be little doubt, therefore, that there are advantages in sampling plants rather than seeds when the objectives of the research are the description and explanation of localised variation.

On the other hand, when the research is concerned with trends over longer distances, local variation is of less importance and the differences between seed and plant samples of the same population are likely to be small compared with the differences between populations. Under these circumstances, seed samples may give results which are as reliable as plant samples and, indeed, Daday's work could not have been accomplished without seed samples.

This report has two objectives. Firstly, there is a need to explain the legitimacy of the phenotype determined by the sodium picrate test and the criteria used for sampling plants in natural habitats. Secondly, the results of sampling populations of mature plants of $L$. corniculatus growing in various localities in western Europe are described and the distribution of the cyanogenic form in this species is compared with that obtained by Daday with T. repens.

\section{Materials ANd methods}

\section{(i) The phenotype and the sodium picrate test}

The basic technique used for testing leaves of plants for cyanogenesis has been described previously (Jones, 1966). In both L. corniculatus and $T$. repens four phenotypes can be distinguished, plants with $\beta$-cyanoglucosides and $\beta$-glucosidase $(++)$, those with cyanoglucosides but no enzyme $(+-)$, those with enzyme but no cyanoglucosides $(-+)$, and those with neither cyanoglucosides nor enzyme (- - ).

With $L$. corniculatus the usual weight of leaf tissue tested is between $15 \mathrm{mg}$ and $25 \mathrm{mg}$ and this gives rise to a threshhold effect which occurs at a concentration of 30 parts per million, the equivalent of $5 \cdot 1 \times 10^{-4} \mathrm{mg}$ of cyanide ion released by $17 \mathrm{mg}$ of leaf tissue (Jones, 1963). Thus any plant which releases less than $30 \times 10 \mu \mathrm{g}$ of volatile HCN per $\mathrm{g}$ of leaf tissue will be scored as acyanogenic. It should be noted that freshly made sodium picrate papers have been used exclusively in my work (Hogg and Ahigren, 1942) and that these papers remained moist throughout incubation. Dry papers must be avoided because it is so easy to obtain false negative results with them. Over the years I have looked for better methods of testing for cyanogenesis and failed. After reviewing the quantitative techniques available for estimating HCN evolution by plant material, Zitnak (1973) has also expressed dissatisfaction with all of them.

There is good evidencc that the test does distinguish between the phenotypic classes upon which selection can be shown to act. During the early stages of the work reported here and following the scheme of Corkill (1942), crude quantitative estimates of the cyanide content of leaves were made by matching the colour changes in sodium picrate papers against a range of colour standards (Jones, 1966). In this way six classes of cyanogenic plants were distinguished. The experiments on selective eating by molluscs used plants of different score for cyanogenesis and it was found that there was 
a good negative relationship between the extent to which a plant was eaten and its score for cyanogenesis (Jones, 1966). Helix aspersa L. for example, gave the result shown in fig. I. It can be concluded, therefore, that the sodium picrate test is biologically meaningful in this context.

\section{(ii) The genetics of cyanogenesis}

For T. repens, cyanogenesis is determined by two alleles at each of two loci, with the glucosidic and enzymic alleles dominant (Corkill, 1942; Attwood and Sullivan, 1943). It has generally been assumed that the

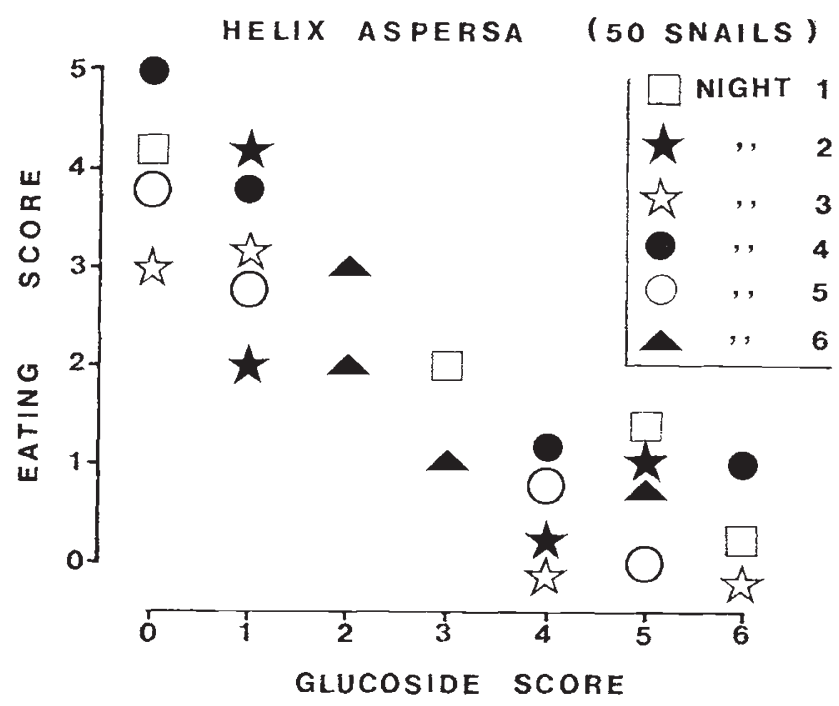

Frg. 1.-Selective eating of Lotus corniculatus by Helix aspersa. Plants with an " eating " score of zero had not been visibly grazed. Plants were given score 5 when all of the stems near the crown of the plant had been damaged or eaten. The cyanide content of a plant was scored according to the method of Corkill (1942). Acyanogenic plants are scored zero and the most strongly cyanogenic plants are scored six. The correlation coefficient, $r[22]=-0.89, \mathrm{P}<<0.001$.

genetic system involved in producing the same range of phenotypes in $L$. corniculatus is identical. There is no evidence to show that this is not true, but the formal breeding work which has been reported is far from conclusive.

Dawson (1941) studied the genetics of "cyanogenesis" and his data show that he did not have segregation at both loci at the same time. He obtained the $35: 1 \mathrm{~F}_{2}$ ratios expected of an autotetraploid segregating at a single locus. Dawson himself states (page 54) that he was studying the genetics of the cyanogenic glycoside. This has always seemed to me to be a reasonable assumption because the acyanogenic plants from Scandinavia which he used were more likely to be -+ than +- (see table 5 ), but Seaney and Henson (1970) believe (page 144) that Dawson was studying the genetics of the enzyme. Further examination of Dawson's paper suggests that if the genetic system is indeed similar to that of $T$. repens, then it is not possible to decide which of the systems he was actually studying. Bansal's (1966) study certainly shows dominance for $\beta$-glucosidase formation and 
some form of tetrasomic inheritance at that locus. The problem with Bansal's work is that he explains his $F_{2}$ ratios for the $\beta$-glucosidase locus by invoking double reduction (chromatid segregation), which requires regular quadrivalent formation, whereas the cytological evidence (Dawson, 1941; Poostchi, 1959; Somaroo and Grant, 1972) shows that quadrivalent formation is a rare occurrence. This is, perhaps, not surprising because the chromosomes in L. corniculatus are small and the chiasma frequency is less than two per bivalent (Wernsman, Keim and Davis, 1964).

The polymorphisms in both $T$. repens and $L$. corniculatus appear to be determined by systems of a simple switch-gene type. Either the plant is cyanogenic or it is acyanogenic. This phenotypic difference may be the result of the rather crude nature of the sodium picrate test used for this work, but because Dawson (1941) obtained good Mendelian ratios the test is reliable enough to show that the phenotypic variation being measured is genetically determined in a simple manner. Although the genetics of cyanogenesis appears to be the same in L. corniculatus and T. repens, this is no reason to suppose that the distribution of the cyanogenic forms will also be the same in these species. It is well known, for example, that the exceedingly similar snails Cepaea nemoralis (L.) and C. hortensis (Müll) have, in the same habitats, responded to the same selection in markedly different ways (Clarke, 1960).

\section{(iii) Quantitative variation in cyanogenic plants}

Although it is apparent that the quantitative differences between cyanogenic plants (e.g. fig. 1) are likely to be important in natural populations, we do not know the genotype of any of the cyanogenic plants we have tested. Consequently it is not known whether this variation is caused principally by allele dosage or is an effect of genes at many loci. There are two main reasons why this work has not been done. Firstly we need much more reliable and sensitive methods for assaying the HCN released by plants. Now that synthetic linamarin is available a start has been made on improving the assay techniques. Secondly, and more important, Jones (1963) noticed that some individual plants of $L$. corniculatus often did not give consistent quantitative results when tested regularly over a period of several months. Subsequently it was discovered that de Waal (1942) and Corkill (1942) had found the same to be true for T. repens. As a prelude to the genetic analysis of the quantitative production of HCN by L. corniculatus, we have been studying the conditions under which the HCN production changes (Ellis, Keymer and Jones, 1977). We also expect to determine the extent to which this characteristic varies both within and between populations.

These changes in the amount of HCN released are presumably the result of increased or decreased production of linamarin and lotaustralin. When testing plants in the wild this plasticity is of major importance when the extreme states of the phenotype lie either side of the threshhold level of detection of HCN. A plant could be acyanogenic at some times of the year and cyanogenic at others. It is for this reason that the months in which plant populations were tested have been included in the tables. As far as the seed samples were concerned, the plants were grown in glasshouses which were maintained at temperatures above $16^{\circ} \mathrm{C}$. It is not unlikely, 
therefore, that the seed samples would give a different estimate of the frequency of the cyanogenic form from the plant samples. To check this, it is necessary to collect a seed sample at the same time and from the same population as the one from which plants are being sampled and being tested for cyanogenesis. The only data available are so scanty as to be not very helpful. There are four pairs of plant and seed samples in tables 2-5, Glaston, Rounds Green, Sundstrup and Wijk aan Zee. Because of the close proximity of alien cyanogenic plants it is not surprising that the frequency of cyanogenesis among the seeds collected from native plants at Sundstrup (Jones, 1973a, and table 5 of this paper) is higher than among the native plants themselves. It is only at Wijk aan Zee that there is a significant difference between the seed and plant samples $\left.\left(x^{2}{ }_{2}\right]=33.61 \mathrm{P}<<0.001\right)$, but this result on its own is of no consequence to the problem being discussed. Brighton and Horne (1977) obtained significant differences between seed and plant samples at Sheriffmuir in Scotland, but their techniques of sampling and testing seeds were so different from those that will be described in this paper that comparison of results is not possible.

The observation that individual plants can have different phenotypes under different conditions (Ellis, Keymer and Jones, 1977) challenges the validity of the estimation of phenotype frequencies in natural populations. Certainly it makes nonsense of any attempts to determine allele frequencies, but as has been argued earlier the phenotype determined by the sodium picrate test does appear to be in the same scale as the one on which selection acts. Consequently, so long as we keep to phenotype frequencies and make comparisons between populations tested at the same time of the year, we have a valid estimate of the structure of a population at the time it was tested. This means that we are justified in making comparisons between years provided we allow that apparent changes in phenotype frequency may be the result of phenotypic instability of the perennial plants quite apart from genuine changes in allele frequency.

\section{(a) Lotus corniculatus}

\section{(iv) The problem of cultivars}

In the U.S.A., L. corniculatus is a major fodder crop being grown in over $8 \times 10^{5}$ hectares in 1967 (Seaney and Henson, 1970). In Britain, on the other hand, L. corniculatus has not achieved the popularity of $T$. repens or Medicago sativa $\mathrm{L}$. either for fodder or for ley, and recent work (Davies, 1969; Charlton, 1973) with modern North American and Russian varieties is not encouraging. In Denmark it is now apparent that seeds from cyanogenic L. corniculatus have occurred as contaminants of the low-grade grass seed used to sow roadside verges (Jones, 1973a). Consequently there is the danger that alien plants may be confused with natural ones. The cultivars are tall, upright plants with broad leaves and long internodes whereas the normal type in northern Europe is prostrate and spreading with small leaves and short internodes. Because of these marked differences both in size and in growth habit it has not been difficult to distinguish between the cultivated and the native form of $L$. corniculatus in the wild (Jones, 1973a).

Cultivated forms of $L$. corniculatus have been found in various localities and the full data to hand are given in table 1. All but two of these samples were of plants growing alongside new roads or recently modified roads. The 
Weissensee and La Pierrière samples differ from the rest in that they were taken from fields sown for winter fodder. In Austria and alpine France, $L$. corniculatus and $T$. repens are regularly added to cocksfoot (Dactylis glomerata L.) and perennial rye-grass (Lolium perenne L.) seed mixtures in proportions similar to those outlined in Robinson (1947). The Italian seed samples (table 5) were the only ones which I did not collect myself and although they were stated to have been obtained in the wild in Tuscany, my experience in Austria in 1972 leaves me doubtful whether the parents were genuinely of wild origin. Furthermore, Professor Scossiroli of Bologna assures me that cultivars of $L$. corniculatus are used extensively in the mountainous regions of northern Italy and are apparently growing wild (see also,

TABLE 1

The occurrence of Lotus corniculatus, with the growth habit of cultivated varieties, on roadside verges in western Europe. These data are not included in any other tables in this paper

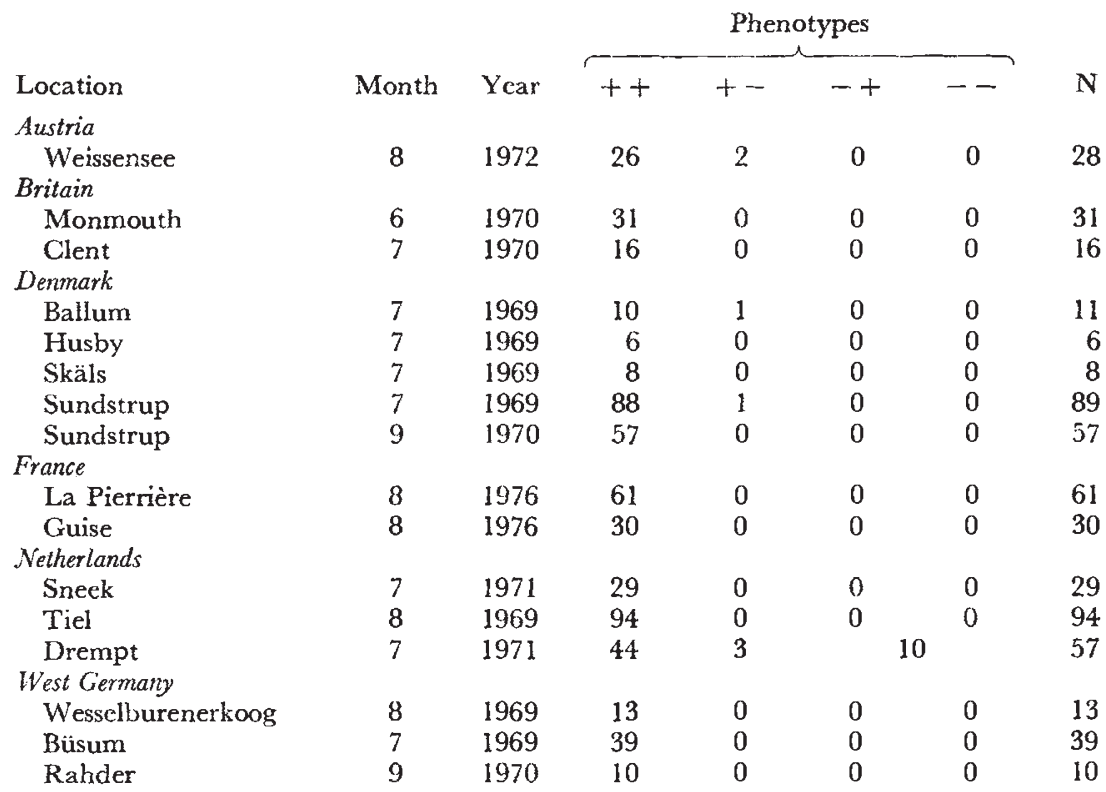

Orsi, 1963). The plants which I have grown from the seeds collected near Erbaia, Filipiomboli and Marcaiano (all in Tuscany) have a morphology very similar to the cultivated forms found in northern France.

Two conclusions can be drawn from the data in table 1. Firstly, whether it is fortuitous or not, it appears that the morphological characters of agronomic importance are now associated with cyanogenesis. Unfortunately it has not been possible to determine the exact source of any of the seed mixtures used on road side verges, essentially because these low-grade mixtures appear to change hands through the trade without adequate records being kept. Secondly, it is clear that uncritical sampling of supposedly wild populations of a species which is of agronomic importance could give rise to highly spurious results, and thence to conclusions of dubious, if any, value. For this reason, the seed sample I collected in 
parkland at Eskilstuna, Sweden (table 5) may not give a true reflection of the frequency of the cyanogenic form amongst native plants of that region and should, perhaps, be ignored.

\section{(b) Trifolium repens}

$T$. repens has been sown much more widely for fodder and ley than $L$. corniculatus and many of the varieties available commercially are almost indistinguishable from native plants. Indeed, it is pertinent to ask whether any $\mathcal{T}$. repens growing in western Europe is uncontaminated. A comparable situation occurs with Vicia angustifolia (L.) Reichard and alien Vicia sativa L. in Britain. Because of the marked introgression of cultivated $V$. sativa into the native $V$. angustifolia most plants show one or more characteristics of $V$. sativa and consequently the two species were amalgamated under one heading - $V$. sativa - in the second edition of Clapham, Tutin and Warburg (1962). T. repens has been used even more extensively for agricultural purposes and so it is very unlikely that "wild" plants occur in England.

Daday (1954a) asked that the seed samples of $T$. repens were to be of wild plants well isolated from any cultivated land or reseeded pasture. In the Haute Savoie Department of France in 1976 I found it impossible to be certain whether any particular group of $\mathcal{T}$. repens plants were wild or cultivated even at altitudes approaching $2000 \mathrm{~m}$. With L. corniculatus, on the other hand, in the exact same localities, there was no difficulty in distinguishing the cultivated varieties.

These arguments challenge the validity of Daday's data and the conclusions which he drew from them. It is, however, highly improbable that, by chance, the acyanogenic form of $\tau$. repens has been sown more frequently in north-east Europe and at high altitude while the cyanogenic form has been sown more frequently in south-west Europe and at low altitude. On the other hand, the frequency of the cyanogenic form in a particular variety may have been a major factor determining the success of that variety in different regions of Europe although, of course, the character itself would not have been measured directly either by the plant breeder or by the grower. It is likely, therefore, that even if all the seeds which Daday grew had been obtained from the descendants of cultivars he would still have been looking at the results of natural selection. For these reasons Daday's data and the large-scale trends in the distribution of the cyanogenic form in western Europe which he demonstrated can be regarded as valid.

\section{(v) Sampling}

Two methods of sampling plants in their natural state have been used. Where plants were clearly distinct, complete enumeration was possible. Only a few groups of young plants growing in recently derelict gravel pits could be scored in this way. All the rest of the data were collected by systematic plant sampling.

L. corniculatus has the ability to propagate vegetatively and so the distance between successive sampling points is important. Harberd $(1958,1961)$ has warned us of the spurious effects which can be obtained if clone formation is ignored. Previous examination of the cloning ability of L. corniculatus suggested that $1 \mathrm{~m}$ was a sufficient distance between sampling points for most purposes (Jones, 1963). On the other hand, the brown keel-colour

$39 / 1-\mathrm{c}$ 
polymorphism (Hart and Wilsie, 1959) enables individual plants to be distinguished and often it has been possible to distinguish, unambiguously, plants growing less than $1 \mathrm{~m}$ apart.

In common with all other methods of sampling the onc used for this work has disadvantages. The error introduced by the cloning of the plants is indeterminate. No record of the exact position of any plant tested was made and therefore pockets of plants of similar phenotype would have been overlooked. This means that non-random distribution of the plants would not have been detected.

On the other hand, there is the advantage that the way in which plants were tested for cyanogenesis is akin to sampling with replacement, in that the individuals are scarcely disturbed. This is important, because unlike in many other studies, the dynamics of the population can in no way be altered by the sampling.

Where plants are arranged at random, systematic and random sampling are equally efficient for obtaining a phenotype frequency for the whole population (Yates, 1971). When plants are not distributed at random, which is the case with L. corniculatus (Usher, 1975), the error of the estimate of phenotype frequency from random sampling is larger than that obtained by systematic area sampling (Yates, 1971; Harberd, 1958) or in other words, a greater difference between two random samples of the same population may be expected than between two systematic area samples. The seeds of a plant are more likely to establish close to that plant and hence non-random distribution may be regarded as likely a priori. Clearly, a bias has been introduced here. Allowances can be made for the non-random distribution of the plants when determining the sampling distance betwcen plants. In addition, calculation of the error of the systematic sample, as if it were a random one, gives rise to an overestimate (Yates, 1971) and hence using this standard error will reduce the chance of spurious significance.

It will be noticed that, unlike in Daday's work (1954 et seq.), only phenotypic frequencies have been used in this paper and in previous reports (e.g. Jones, 1970). The main reason why allele frequencies are not used is that the glucoside locus in $L$. corniculatus apparently shows tetrasomic inheritance. For example, suppose that the frequency of the acyanogenic form in a population of $L$. corniculatus is 1 per cent. The estimated frequency of the aglucoside allele is 31.62 per cont. Thus it is possible to infer that the $\beta$-glucoside allele is absent from a sample of 100 plants or more even though its frequency may be as high as 30 per cent. Even with diploids, a sample of 100 exclusively cyanogenic plants can overlook a recessive allele frequency of 10 per cent. It is clear, therefore, that it is much wiser to use the phenotype frequency instead of the estimated allele frequencies when comparing samples.

Furthermore, the ability of both of these leguminous species to reproduce and spread vegetatively could make the determination of allele frequencies in natural populations highly dubious. The problem is that when a plant clones, we do not know what constitutes an individual. It was stated earlier that a minimum distance between two sampling points of $1 \mathrm{~m}$ has been used throughout this work. For consistency, therefore, the plant material collected at these sampling points is assumed to have been obtained from separate plants and so phenotype frequencies have been calculated accordingly. 


\section{Results}

The results of sampling groups of L. corniculatus plants in Britain and on the mainland of western Europe are given in tables 2-5. Details about the localities listed are available from the Brynmor Jones Library, University of Hull.

Where it was not possible to test plants in their natural habitat, seed samples were collected. One ripe pod per plant was taken from as many individuals as possible in each group of plants. Samples of the seeds were grown in the glasshouse and only when there was a high germination and establishment rate were the resulting plants scored for cyanogenesis. Many

TABle 2

Samples of Lotus corniculatus plants growing in Britain which have been tested for cyanogenesis. The localities have been listed with the most northerly first

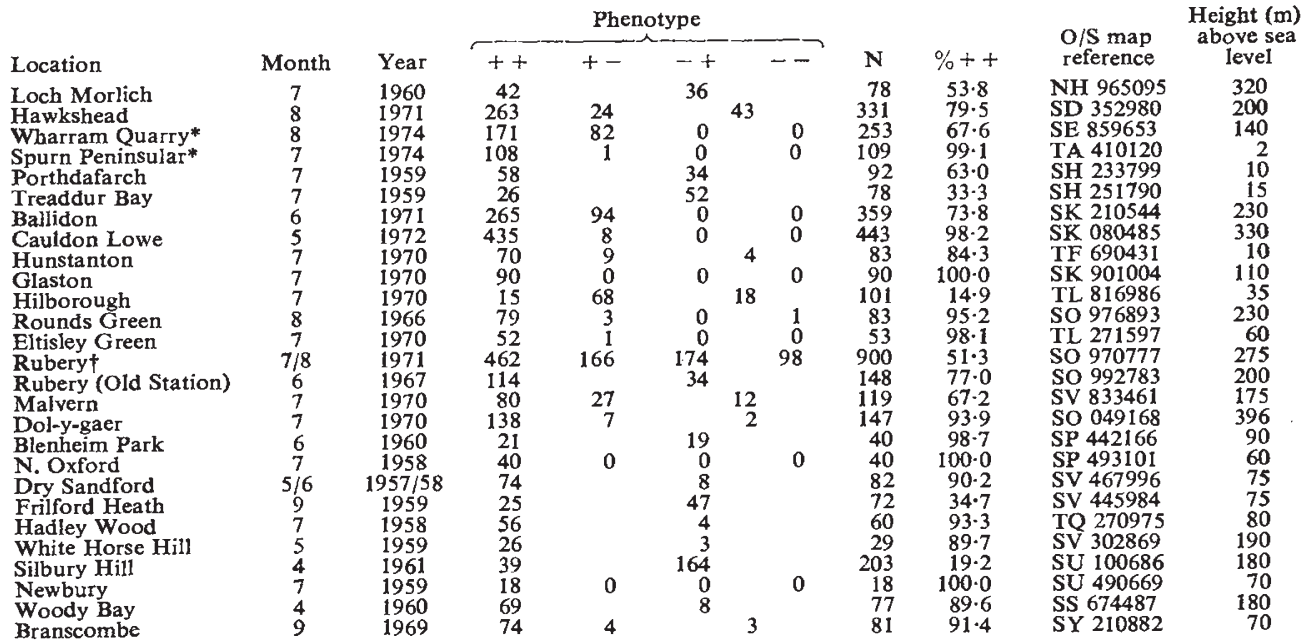

* Data of Dr W. Mary Ellis and Mr Richard Keymer.

+ Data of Dr T. J. Crawford.

more locations have been sampled than are indicated by the data listed in these tables. For example, where samples from different locations in the same area were not heterogeneous, they have been pooled for presentation in fig. 2 and fig. 3. The data for the Netherlands and Denmark have been presented elsewhere in greater detail (Jones, 1972, 1973a; Ellis, Keymer and Jones, 1976) while the results of sampling near and around Büsum in Schleswig-Holstein are given separately in table 8.

\section{(i) Cyanogenesis in Europe}

The overall distribution of the cyanogenic form of $L$. corniculatus in western Europe (fig. 2) does not correspond in any precise way with the elegant picture obtained by Daday (1954a) for T. repens. It is clear, however, that there is a decline in the frequency of the cyanogenic form of $L$. corniculatus from the south-west to the north-east, with a tendency for acyanogenic plants to be commoner in Scandinavia than elsewhere. 
Table 3

Samples of Lotus corniculatus plants growing on the mainland of Europe which have been tested for cyanogenesis

\begin{tabular}{|c|c|c|c|c|c|c|c|c|}
\hline \multirow[b]{2}{*}{ Location } & \multirow[b]{2}{*}{ Month } & \multicolumn{4}{|c|}{ Phenotype } & & & \multirow[b]{2}{*}{$\begin{array}{c}\text { Approx. } \\
\text { height }(\mathrm{m}) \\
\text { above sea } \\
\text { level }\end{array}$} \\
\hline & & Year & ++ & +- & $\begin{array}{c}(-+ \\
\text { or } \\
--)\end{array}$ & $\mathrm{N}$ & $\%++$ & \\
\hline \multicolumn{9}{|l|}{ Denmark* } \\
\hline Sundstrup & 9 & 1970 & 3 & 8 & 83 & 94 & $3 \cdot 2$ & 15 \\
\hline Ringkøbing & 7 & 1969 & 0 & 0 & 100 & 100 & 0 & 15 \\
\hline Rømø & 7 & 1969 & 0 & 2 & 103 & 105 & 0 & 2 \\
\hline Barde & 9 & 1970 & 1 & 5 & 50 & 56 & $1 \cdot 8$ & not known \\
\hline \multicolumn{9}{|l|}{$\begin{array}{c}\text { Barde } \\
\text { West Germany } \dagger\end{array}$} \\
\hline Dagebüll arca & 7 & 1969 & 2 & 16 & 98 & 116 & 1.7 & $2-5$ \\
\hline Lentföhrden & 8 & 1969 & 1 & 2 & 107 & 110 & 0.9 & 30 \\
\hline Rethem & 8 & 1969 & 39 & 2 & 8 & 49 & $79 \cdot 6$ & 20 \\
\hline Büsum & 8 & 1969 & 125 & 23 & 0 & 148 & $84-5$ & $2-5$ \\
\hline Itzehoe & 8 & 1969 & 0 & 2 & 45 & 47 & 0 & 20 \\
\hline \multicolumn{9}{|l|}{ Netherlands ${ }_{+}^{+}$} \\
\hline Callantsoog & 9 & 1970 & 0 & 4 & 71 & 75 & 0 & 5 \\
\hline Oude Merdum & 7 & 1971 & 0 & 0 & 159 & 159 & 0 & 5 \\
\hline Wageningen & 7 & 1971 & 95 & 3 & 1 & 99 & $96 \cdot 0$ & 4 \\
\hline Wassenaar & 7 & 1971 & 62 & 7 & 9 & 78 & $79 \cdot 5$ & 4 \\
\hline Wijk aan Zee & 9 & 19.70 & 14 & 11 & 25 & 50 & $28 \cdot 0$ & 10 \\
\hline Veenendaal & 7 & 1971 & 0 & 2 & 49 & 51 & 0 & 9 \\
\hline Zaltbommel & 7 & 1969 & 103 & 0 & 0 & 103 & $100 \cdot 0$ & 6 \\
\hline \multicolumn{9}{|l|}{$\begin{array}{l}\text { Zaltbommel } \\
\text { France }\end{array}$} \\
\hline Lisieux & 8 & 1971 & 36 & & 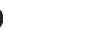 & 36 & $100 \cdot 0$ & 150 \\
\hline Poitiers§ & 8 & 1970 & 40 & & 3 & 48 & $83-3$ & not known \\
\hline Crêt de Châtillon & 8 & 1976 & 0 & 0 & 64 & 64 & 0 & 1540 \\
\hline Col de la Forclaz & 8 & 1976 & 1 & 14 & 29 & 44 & $2 \cdot 27$ & 1225 \\
\hline Synclinal de Bisanne & & & & & & & & \\
\hline (Savoie) & 8 & 1976 & 3 & & 7 & 40 & $7 \cdot 5$ & 1870 \\
\hline Guise & 8 & 1976 & 25 & 0 & 0 & 25 & $100 \cdot 0$ & 95 \\
\hline \multicolumn{9}{|l|}{ Austria } \\
\hline Unterberghorn & 7 & 1972 & 38 & & 8 & 86 & $44 \cdot 2$ & 950 \\
\hline Weissensee & 8 & 1972 & 0 & & 5 & 65 & 0 & 950 \\
\hline \multicolumn{9}{|l|}{$\begin{array}{l}\text { Weissensee } \\
\text { Spain }\end{array}$} \\
\hline Comillas (Santander) & 8 & 1970 & 64 & & 1 & 65 & $98 \cdot 5$ & 5 \\
\hline Fuente Dé (Santander) & 8 & 1970 & 20 & & 8 & 48 & $41 \cdot 7$ & 1800 \\
\hline Oriñon (Santander) & 8 & 1970 & 51 & & 0 & 51 & $100-0$ & 30 \\
\hline $\begin{array}{l}\text { Collado de Corbet } \\
\text { (Gerona) }\end{array}$ & 7 & 1971 & 1 & & & 102 & $1 \cdot 0$ & 1010 \\
\hline
\end{tabular}

* Further data in Jones (1973a).

$\uparrow$ Further data in table 8 of this paper. A map will be found in Jones (1973b).

* Further data in Jones (1972) and in Ellis, Keymer and Jones (1976).

$\S$ Lotus tenuis Waldst. and Kit ex Willd. occurred at this site, but was not tested.

Table 4

Samples of Lotus corniculatus seeds collected from plants growing in England and Wales which have been tested for cyanogenesis

\begin{tabular}{|c|c|c|c|c|c|c|c|c|c|c|}
\hline \multirow[b]{2}{*}{ Location } & \multirow[b]{2}{*}{ Month } & \multirow[b]{2}{*}{ Ycar } & \multicolumn{4}{|c|}{ Pneno } & \multirow[b]{2}{*}{$\mathbf{N}$} & \multirow[b]{2}{*}{$\%++$} & \multirow{2}{*}{$\begin{array}{l}\text { O/S map } \\
\text { reference }\end{array}$} & \multirow{2}{*}{$\begin{array}{c}\text { above sea } \\
\text { level }\end{array}$} \\
\hline & & & ++ & +- & -+ & -- & & & & \\
\hline $\begin{array}{l}\text { Aysgarth } \\
\text { Glaston } \\
\text { Llanidloes } \\
\text { Rounds Green } \\
\text { Cwm-yr-eglwys } \\
\text { Denbies } \\
\text { Nare Head } \\
\text { St Anthony Head } \\
\text { Porthscatho } \\
\text { Kynance Cove }\end{array}$ & $\begin{array}{c}9 \\
7 \\
10 \\
8-9 \\
8 \\
10 \\
7 \\
7 \\
7 \\
8\end{array}$ & $\begin{array}{l}1960 \\
1970 \\
1958 \\
1966 \\
1969 \\
1958 \\
1967 \\
1967 \\
1967 \\
1967\end{array}$ & $\begin{array}{r}93 \\
55 \\
35 \\
520 \\
50 \\
27 \\
65 \\
77 \\
109 \\
27\end{array}$ & $\begin{array}{r}2 \\
5 \\
50 \\
8 \\
0 \\
1 \\
3 \\
3 \\
1 \\
9\end{array}$ & $\begin{array}{r}1 \\
0 \\
5 \\
0 \\
0 \\
2 \\
1 \\
0 \\
0 \\
14\end{array}$ & $\begin{array}{r}0 \\
0 \\
20 \\
8 \\
0 \\
0 \\
0 \\
0 \\
0 \\
3\end{array}$ & $\begin{array}{r}96 \\
60 \\
110 \\
536 \\
50 \\
30 \\
69 \\
80 \\
110 \\
53\end{array}$ & $\begin{array}{r}96 \cdot 9 \\
91 \cdot 7 \\
31 \cdot 8 \\
97 \cdot 0 \\
100 \cdot 0 \\
90 \cdot 0 \\
94 \cdot 2 \\
96 \cdot 3 \\
99 \cdot 1 \\
50 \cdot 9\end{array}$ & $\begin{array}{l}\text { SE } 026888 \\
\text { SK } 901004 \\
\text { SN } 955845 \\
\text { SO } 986893 \\
\text { SN } 014401 \\
\text { TQ } 155506 \\
\text { SW } 917373 \\
\text { SW } 848313 \\
\text { SW } 880352 \\
\text { SW } 685134\end{array}$ & $\begin{array}{r}150 \\
110 \\
305 \\
230 \\
10 \\
152 \\
90 \\
45 \\
5 \\
20\end{array}$ \\
\hline
\end{tabular}


One of the most convincing aspects of Daday's work with T. repens was his discovery that there was a decline in the frequency of both the $\beta$ glucoside and the $\beta$-glucosidase forms of this plant in seed samples collected at successively higher locations in the Alps (Daday, 1954b). His hypothesis that the correlation between the distribution of the cyanogenic form of $T$. repens and January mean temperature was biologically meaningful stood or fell by that alpine data. More recently the association between the frequency of cyanogenesis and altitude has been confirmed by de Araújo (1976) who sampled $T$. repens plants in the mountains of north Wales.

TABLE 5

Samples of Lotus corniculatus seeds collected from plants growing on the mainland of Europe which have been tested for cyanogenesis

\begin{tabular}{|c|c|c|c|c|c|c|c|c|c|}
\hline \multirow[b]{2}{*}{ Location } & \multirow[b]{2}{*}{ Month } & \multirow[b]{2}{*}{ Year } & \multicolumn{4}{|c|}{ Phenotype } & \multirow[b]{2}{*}{$N$} & \multicolumn{2}{|r|}{ Height $(m)$} \\
\hline & & & ++ & +- & -+ & -- & & $\%++$ & level \\
\hline \multicolumn{10}{|l|}{ Sweden } \\
\hline Eskilstuna & 8 & 1961 & 109 & 10 & 33 & 7 & 159 & $68 \cdot 6$ & not known \\
\hline Sannäs & 8 & 1961 & 0 & 0 & 6 & 43 & 49 & 0 & 2 \\
\hline Halleviksstrand & 8 & 1961 & 2 & 12 & 7 & 154 & 175 & $1 \cdot 1$ & 3 \\
\hline Orust & 8 & 1961 & 0 & 0 & 5 & 62 & 67 & 0 & 3 \\
\hline \multicolumn{10}{|l|}{ Denmark } \\
\hline Ábenrå & 8 & 1961 & 0 & 0 & 4 & 29 & 33 & 0 & 15 \\
\hline Sundstrup & 8 & 1969 & 12 & 24 & \multicolumn{2}{|c|}{97} & 133 & $9 \cdot 0$ & 15 \\
\hline \multicolumn{10}{|l|}{ West Germany } \\
\hline Risum & 9 & 1970 & 2 & 14 & \multicolumn{2}{|c|}{73} & 89 & $2 \cdot 2$ & 10 \\
\hline \multicolumn{10}{|l|}{ Netherlands } \\
\hline Den Helder & 9 & 1970 & 0 & 17 & 8 & 33 & 58 & 0 & 12 \\
\hline Wijk aan Zee & 9 & 1970 & 41 & 48 & 2 & 6 & 97 & $42 \cdot 3$ & 10 \\
\hline \multicolumn{10}{|l|}{ France } \\
\hline Concarneau & 7 & 1968 & 95 & 3 & 0 & 0 & 98 & $96 \cdot 9$ & 20 \\
\hline St. Georges de Didonne & 8 & 1968 & 98 & 0 & 0 & 0 & 98 & $100 \cdot 0$ & 5 \\
\hline \multicolumn{10}{|l|}{ Italy } \\
\hline Tuscany ( 3 localities) ${ }^{*}$ & 7 & 1966 & 185 & 0 & 0 & 0 & 185 & $100 \cdot 0$ & not known \\
\hline \multicolumn{10}{|l|}{ Spain } \\
\hline Guetaria (Guipúzcoa) & 7 & 1970 & 85 & 0 & 0 & 0 & 85 & $100 \cdot 0$ & 50 \\
\hline Zarragoza $†$ & 8 & 1970 & 11 & 4 & & 1 & 56 & $19 \cdot 6$ & 200 \\
\hline
\end{tabular}

* Supplied by Dr Paolo Talamucci, University of Florence.

$\dagger$ Lotus tenuis growing at this site was not tested.

Data for $L$. corniculatus collected in July 1975 by my colleagues Mary Ellis and Richard Keymer show that there is no relationship between the frequency of cyanogenic plants and altitude for plants growing at 21 locations in Scotland even though the range in frequency is from 9 per cent to 76 per cent cyanogenic plants (tables 6 and 7). It should be noted that all four locations where Brighton and Horne (1977) tested L. corniculatus are included in table 6 and so we must conclude that their data are inadequate. There is other evidence that altitude may not be important in determining the frequency of cyanogenic $L$. corniculatus. I have collected samples from five separate groups of plants growing at over $1000 \mathrm{~m}$ (table 3). The two samples at the highest altitudes, Fuente Dé and Synclinal de Bisanne, contained 41.7 per cent and 7.5 per cent of cyanogenic plants, respectively, whereas at the three lower altitudes the frequencies were zero, 1 and 2.27 per cent. Fifteen plants from Synclinal de Bisanne have been grown in the 
glasshouse at Hull and none fits the descriptions of Lotus alpinus (DC) Schleicher ex Raymond (Tutin et al., 1968). These plants were screened because when sampling $\mathcal{L}$. corniculatus at high altitudes in the Alps care must be taken to avoid possible confusion with $L$. alpinus, a species which is also polymorphic for cyanogenesis (Urbanska-Worytkiewicz and Wildi, 1975).

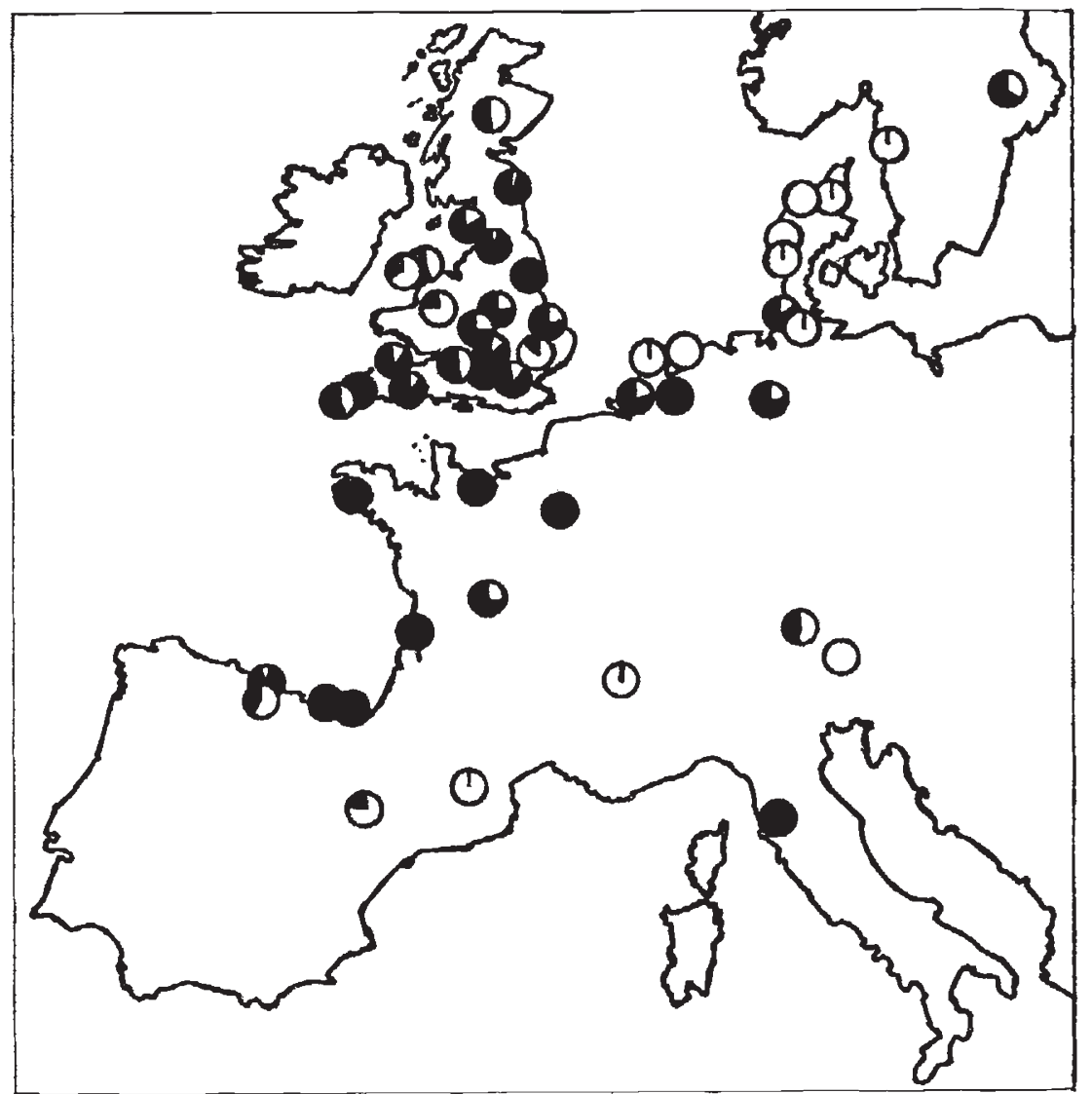

FrG. 2.-The distribution of the cyanogenic forms of Lotus corniculatus amongst wild populations. The black sectors indicate the percentage of cyanogenic plants.

\section{(ii) Localised variation}

Sampling groups of plants growing close together has revealed significant differences in the frequency of the cyanogenic form over short distances. Several localities in which this occurs have been listed elsewhere (Jones $1968,1970,1972,1973 b)$ and the interpretation of these observations will not be repeated here.

A region which is clearly aberrant is near Büsum in Schleswig-Holstein (table 8). The sampling has been as extensive as time and the occurrence of plants would allow, but there is little doubt about the localised nature of the distribution of the cyanogenic plants. The gaps in the map (Jones, 


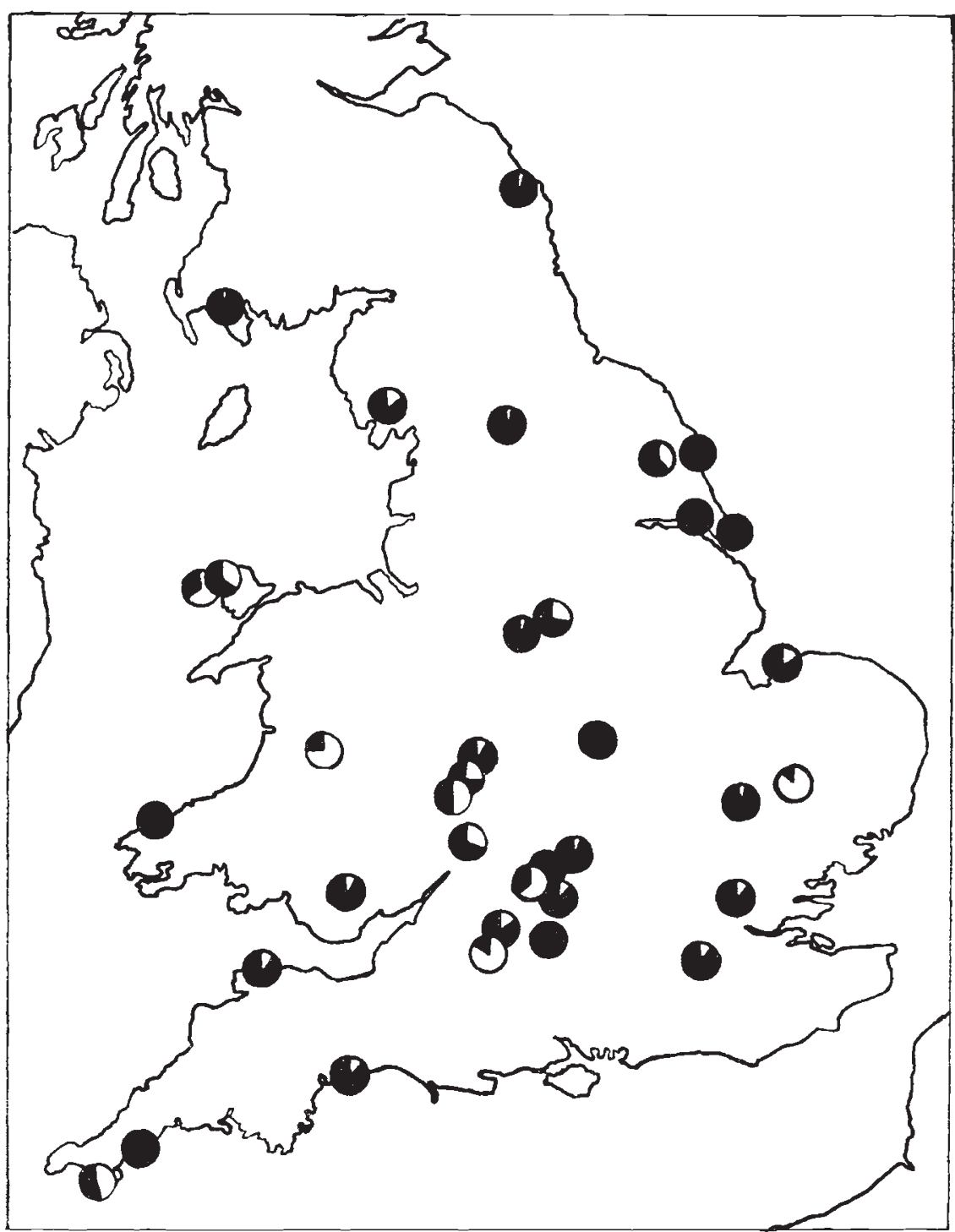

FIG. 3.- The distribution of the cyanogenic form of Lotus corniculatus in England, Wales and southern Scotland. The black sectors indicate the percentage of cyanogenic plants.

$1973 b$ ) especially to the north and to the south of the Büsum Peninsular merely indicate that plants were not found in those regions. The land between Heide and Büsum is very similar to the polder of the Netherlands; there is very little "waste" land and there are few suitable habitats for $L$. corniculatus other than on the dykes, although as expected, Lotus uliginosus Schkuhr occurs commonly at the side of the numerous drainage channels. The cyanogenic plants of $L$. corniculatus are not confined, however, just to the sea dykes, even though it was plants on these dykes which were sampled first. 
In the Büsum region two types of cyanogenic plants occur which are morphologically distinct. One type is the cultivated form (included in table 1) and, although they were roadside groups of plants, there was no real evidence of recent road works. The other type is the typical prostrate form of northern Europe described earlier. L. corniculatus was used agronomically in Schleswig-Holstein and Jutland (personal comment from Professor Kai Larsen of Aarhus) until 1940 approximately and so the prostrate cyanogenic plants of Büsum may well be relics of cultivation. The agronomic strains of 30 years ago (Robinson, 1947) had similar morphological characteristics to cultivated varieties used today and therefore it would seem that selection in the Büsum area has been stronger against the alien forms of plant morphology and growth habit than against alien cyanogenesis.

TABle 6

The frequency of cyanogenic Lotus comiculatus at different altitudes in Scotland. All the sampling sites were no more than $80 \mathrm{~km}$ from Perth. The dala were collected in July 1975

$\begin{array}{cccccc}\begin{array}{c}\text { Altitude } \\ \text { in metres }\end{array} & \begin{array}{c}\text { Percentage } \\ \text { cyanogenic } \\ \text { plants }\end{array} & \begin{array}{c}\text { Total } \\ \text { Altitude } \\ \text { in metres }\end{array} & \begin{array}{c}\text { Percentage } \\ \text { cyanogenic } \\ \text { plants }\end{array} & \text { Total } \\ 10 & 46 & 100 & 310^{*} & 25 & 32 \\ 15 & 30 & 20 & 320 & 54 & 50 \\ 60 & 79 & 19 & 365 & 44 & 48 \\ 110^{*} & 24 & 50 & 410 & 76 & 46 \\ 170^{*} & 38 & 80 & 440 & 24 & 50 \\ 170 & 43 & 35 & 460 & 51 & 49 \\ 230 & 9 & 32 & 560 & 62 & 26 \\ 235 & 76 & 42 & 610 & 14 & 42 \\ 305 * & 36 & 33 & 690 & 29 & 28 \\ 305 & 27 & 45 & 850 & 20 & 86 \\ & 23 & 75 & & & \end{array}$

* Locations at which Brighton and Horne (1977) tested L. corniculatus.

TABLE 7

Analysis of variance of regression for the frequency of cyanogenic plants (in angles) against height above sea leavel

$\begin{array}{lrl} & \text { d.f. } & \text { M.S. } \\ \text { Regression } & 1 & 136.35 \text { not significant } \\ \text { Residual } & 19 & 191.94\end{array}$

\section{Discussion}

This is the first attempt at a population survey of cyanogenesis in $L$. corniculatus and it has not been possible to suggest an explanation for cyanogenesis in this species in the way in which Daday (1965) did for T. repens. Instead each habitat has to be studied in detail and the relative contribution of the known selective agents have to be examined in each situation. Mature plants have been tested in their natural habitats in various countries in Europe and there are now sufficient data to demonstrate why no general hypothesis is possible. In L. corniculatus there is an overall change in the frequency of the cyanogenic form from Spain, across Europe to Scandinavia. In $T$. repens it is gradual, whereas with $L$. corniculatus it appears to occur as a 
TABLE 8

Samples of Lotus corniculatus plants growing in West Germany which have been tested for cyanogenesis. The 1969 samples were collected in July and August. In 1970 the samples were collected in September. The locations have been arranged in order from North to South except that the Albersdorf sites are at exactly the same latitude as the Büsum sites, but $25 \mathrm{~km}$ inland.

\begin{tabular}{|c|c|c|c|c|c|c|c|}
\hline \multirow[b]{2}{*}{ Location } & \multicolumn{4}{|c|}{ Phenotype } & \multirow[b]{2}{*}{$\mathbf{N}$} & \multirow[b]{2}{*}{$\%++$} & \multirow{2}{*}{$\begin{array}{l}\text { Approx. } \\
\text { height above } \\
\text { sea level } \\
\text { in } m\end{array}$} \\
\hline & Year & ++ & +- & $\begin{array}{c}(-+ \text { or } \\
--)\end{array}$ & & & \\
\hline Risum & 1970 & 0 & 1 & 17 & 18 & 0 & 10 \\
\hline Dagebüll & 1969 & 0 & $i$ & 20 & 21 & 0 & $2-5$ \\
\hline Bargum & 1970 & 0 & 2 & 19 & 21 & 0 & $2-5$ \\
\hline Solwitt & 1969 & 0 & 8 & 23 & 31 & 0 & 30 \\
\hline Arlewatt & 1969 & 2 & 7 & 55 & 64 & $3 \cdot 1$ & 20 \\
\hline Weddingstedt & 1969 & 0 & 2 & 21 & 23 & 0 & 10 \\
\hline Wesselburenerkoog & 1969 & 4 & 1 & 31 & 36 & $11 \cdot 1$ & 2 \\
\hline Schalkholz & 1969 & 0 & 0 & 20 & 20 & 0 & 20 \\
\hline Albersdorf north & 1970 & 0 & 4 & 19 & 23 & 0 & 30 \\
\hline Albersdorf south & 1970 & 0 & 1 & 10 & 11 & 0 & 12 \\
\hline Reinsbüttel & 1970 & 42 & 1 & 0 & 43 & $97 \cdot 7$ & $2-5$ \\
\hline Büsum 1 & 1969 & 12 & 4 & 1 & 17 & $70 \cdot 1$ & $2-5$ \\
\hline 2 & 1969 & 41 & 4 & 5 & 50 & $92 \cdot 0$ & $2-5$ \\
\hline 3 & 1969 & 39 & 2 & 0 & 41 & $95 \cdot 1$ & $2-5$ \\
\hline 4 & 1969 & 36 & 2 & 3 & 41 & $87 \cdot 8$ & $2-5$ \\
\hline 5 & 1969 & 125 & 23 & 0 & 148 & $84 \cdot 5$ & $2-5$ \\
\hline 5 & 1970 & 21 & 6 & 3 & 30 & $70 \cdot 0$ & $2-5$ \\
\hline east & 1969 & 19 & 3 & 0 & 22 & $86 \cdot 4$ & $2-5$ \\
\hline Meldorferhafen & 1969 & 27 & 9 & 3 & 39 & $69 \cdot 2$ & $2-5$ \\
\hline Krumstedt & 1970 & 0 & 1 & 40 & 41 & 0 & 20 \\
\hline Oldenborstel & 1970 & 0 & 3 & 22 & 25 & 0 & 30 \\
\hline Itzehoe & 1969 & 0 & 2 & 45 & 47 & 0 & 20 \\
\hline Lentföhrden & 1969 & 1 & 2 & 107 & 110 & 0.9 & 30 \\
\hline Warstade & 1969 & 3 & 4 & 10 & 17 & $17 \cdot 6$ & 3 \\
\hline Bukholz & 1969 & 0 & 0 & 26 & 26 & 0 & not known \\
\hline
\end{tabular}

stepped cline over a distance of $150 \mathrm{~km}$ in the Netherlands. In both species significant changes in frequency occur over short distances (Jones, 1968, $1970,1972$ and $1973 a, b)$. I have been able to explain some of these situations for $L$. corniculatus, but for $T$. repens the introduction of cultivars is a possibility which cannot be checked.

It was hoped that the studies on L. corniculatus in the Netherlands would have led to an explanation of the cline in that country, but this has not happened (Jones, 1972; Ellis, Keymer and Jones, 1976). A clear association was found between the frequency of the cyanogenic form and latitude, but the metereological records for the period 1951-60 (Klimatologische Gegevens, 1969) revealed no variable which could be correlated with latitude in that region. The west coast of the Netherlands has a remarkably uniform climate, even though it stretches for a distance of $150 \mathrm{~km}$ between latitudes $51^{\circ} 50^{\prime}$ and $53^{\circ} \mathrm{N}$. For the clines in Pinus silvestris L. (Langlet, 1959) and Drosophila melanogaster (David and Bocquet, 1975) it is clear that the latitudinal effects are general because the published evidence shows that all the populations which have been examined fit on one cline. A different situation exists with the cline for leaf papillae in Dactylis marina Borrill along the coast of Portugal (Benson and Borrill, 1969). There is no evidence whether the cline exists in other populations of $D$. marina at the same latitude. 
Other examples, in England, are the latitudinal clines for the character of papillae on the seeds of Spergula arvensis L. (New, 1958), spotting on the leaves of Arum maculatum L. (Prime, 1955) and for $\beta$-chromosomes in the grasshopper Myrmeleotettix maculatus (Hewitt and Brown, 1970). It is not known whether similar clines exist in these species on the mainland of Europc. Similar difficulties arise when attempting comparisons with work outside Europe (e.g. Epling, Lewis and Ball, 1960; Cook, 1962; Masaki, 1967).

For cyanogenesis in $L$. corniculatus, however, data collected at the same latitude in Britain can be compared directly with that of the Netherlands. The data in table 2 show that there is no decline in the frequency of cyanogenic plants in England between the latitudes $51^{\circ} 45^{\prime} \mathrm{N}$. (Oxford) and $53^{\circ} \mathrm{N}$. (Cauldon Lowe) (see fig. 3). Glearly the effect of latitude is not a general one for $L$. corniculatus.

The studies of the polymorphism of cyanogenesis in L. corniculatus and T. repens have revealed morph ratio clines at three levcls. Daday (1954a) obscrved a gradual change in the frequency of the cyanogenic form of $T$. repens over the continent of Europe, whereas I (Jones, 1972) demonstrated a comparable change in $L$. corniculatus over $100 \mathrm{~km}$. On a smaller scale, both for $T$. repens and for $L$. corniculatus (Jones 1970, 1973a, b), significant differences in frequency have been found between groups of plants growing only a few metres apart.

It is not possible to suggest an overall hypothesis to explain these clines. Certainly there is no simple cause-and-effect relationship controlling the distribution of the cyanogenic phenotype of $L$. corniculatus. We know that under some conditions selective grazing, soil water content and perhaps temperature are important and yet it is clear that not one of these predominates in the way that Daday (1965) was able to demonstrate winter temperaturc as the principal selective agent on cyanoglucoside production in $T$. repens. Even that work failed to demonstrate a diffcrential effect of temperature on cyanogenic plants.

Acknowledgments.-Because the work reported in this paper has spanned 19 years, in different ways and at different times various people have given help and encouragement. I thank all those people and the Science Rescarch Council for financial support (B/SR/6494 and $\mathrm{B} / \mathrm{R} \mathrm{x} / 33539)$. The constructive comments of Professor A. J. Cain on an carlier draft of this papcr are gratefully acknowledged.

\section{REFERENCES}

DE ARıÚJO, A. м. 1976. The relationship betwecrn altitude and cyanogenesis in white clover (Trifolium repens L.). Heredity, 37, 291-293.

ATTWOOD, s. S., AND sut.IVAN, J. T. 1943. Inheritance of a cyanogenic glucoside and its hydrolyzing enzymc in Trifolium repens. F. Hered., 34, 311-320.

BANSAL, R. D. 1966. Studics on procedures for combining clones of Birdsfoot Trcfoil, Lotus corniculatus L. Ph.D. Thesis, Cornell University, U.S.A.

BENSON, M., AND BORRIL, M. 1969. The significance of clinal variation in Dactylis marina Borrill. Nete Phytol., 68, 1159-1173.

BRIEHTON, F., AND IIORNE, M. T. 1977. Influence of temperature on cyanogenic polymorphisms. Nature, 265, 437-438.

Charlton, J. F. L. 1973. The potential value of birdsfoot trefoils (Lotus spp.) for the improvement of natural pastures in Scotland. 7. Brit. Soc., 28, 91-96.

Clapilam, A. R., Tutin, T. J., And Warburg, E. F. 1962. Flora of the British Isles, 2nd Edition. Cambridge University Press. 
GLARkE, B. C. 1960. Divergent effects of natural selection on two closely-related polymorphic snails. Heredity, 14, 423-443.

cook, s. A. 1962. Genetic system, variation and adaptation in Eschoscholzia californica. Evolution, 16, 278-299.

CORKILL, L. 1942. Cyanogenesis in white clover (Trifolium repens L.). V. The inheritance of cyanogenesis. N.Z.F. Sci. Tech., 23 B. 178-193.

DADAY, H. 1954a. Gene frequencies in wild populations of Trifolium repens. I. Distribution by latitude. Heredity, 8, 61-78.

DADAY, H. 1954b. Gene frequencies in wild populations of Trifolium repens. II. Distribution by altitude. Heredity, 8, 377-384.

DADAX, H. 1958. Gene frequencies in wild populations of Trifolium repens L. III. World distribution. Heredity, 12, 169-184.

DADAX, H. 1965. Gene frequencies in wild populations of Trifolium repens L. IV. Mechanism of natural selection. Heredity, 20, 355-365.

DAVID, J. R., AND BOCQUET, C. 1975. Evolution in a cosmopolitan species: genetic latitudinal clines in Drosophila melanogaster wild populations. Experientia, 31, 164-166.

Davies, w. E. 1969. The potential of Lotus spp. for hill land in Wales. J. Brit. Grass. Soc., 24, 264-270.

DAWSON, C. D. R. 1941. Tetrasomic inheritance in Lotus corniculatus L. 7. Genetics, 42, 49-72. ELLIS, W. M., KEXMER, R. J., AND JONES, D. A. 1976. On the polymorphism of cyanogenesis in Lotus corniculatus L. VI. Ecological studies in the Netherlands. Heredity, 36, 245-251.

ELLIS, W. M., KEYMER, R. J., AND JONES, D. A. 1977. The effect of temperature on the polymorphism of cyanogenesis in Lotus corniculatus L. Heredity, 38, 339-347.

EPLING, C., LEWIS, H., AND BALL, F. M. 1960. The breeding group and seed storage: a study in population dynamics. Evolution, 14, 238-255.

haRberd, D. J. 1958. Progress and prospects in genecology. Scottish Plant Breeding Station Report for 1958, p. 52 .

HARBERD, D. J. 1961. The case for extensive rather than intensive sampling in genecology. The New Phytologist, 60, 325-338.

HART, R. H., AND WILSIE, c. P. 1959. Inheritance of a flower character, brown keel tip, in Lotus corniculatus L. Agron. 7., 51, 379-380.

HEWITT, G. M., AND BROWN, F. M. 1970. The $\beta$-chromosome system of Myrmeleotettix maculatus. V. A steep cline in East Anglia. Heredity, 25, 363-371.

HOGG, P. J., AND AHLGREN, H. L. 1942. A rapid method for determining hydrocyanic acid content of single plants of Sudan grass. F. Am. Soc. Agron., 34, 199-200.

JONES, D. A. 1963. D.Phil. Thesis, University of Oxford, England.

JONES, D. A. 1966. On the polymorphism of cyanogenesis in Lotus corniculatus. Selection by animals. Canad. 7. Genet. Cytol., 8, 556-567.

JONES, D. A. 1968. On the polymorphism of cyanogenesis in Lotus corniculatus L. II. The interaction with Trifolium repens $\mathrm{L}$. Heredity: 23, 453-455.

JONES, D. A. 1970. On the polymorphism of cyanogenesis in Lotus corniculatus L. III. Some aspects of selection. Heredity, 25, 633-647.

JONES, D. A. 1972. On the polymorphism of cyanogenesis in Lotus corniculatus L. IV. The Netherlands. Genetica, 43, 394-406.

JONES, D. A. 1973a. On the polymorphism of cyanogenesis in Lotus corniculatus L. V. Denmark. Heredity, 30, 381-386.

JONES, D. A. 1973b. Coevolution and cyanogenesis. In Taxonomy and Ecology, ed. V. H. Heywood, pp. 213-242. Academic Press, London.

KLIMATOLOGISCHE GEGEVENS VAN NEDERLANDES STATIONs. 1969. No. 2. Averages for the period 1951-1960. Royal Netherlands Meteorological Institute, De Bilt.

LANGLET, O. 1959. A cline or not a cline-a question of Scots Pine. Silvae Genetica, 8, 14-22.

MASAKI, sINZO. 1967. Geographic variation and climatic adaptation in a field cricket (Orthoptera: Gryllidae). Evolution, 21, 725-741.

NEW, J. 1958. A population study of Spergula arvensis. I. Two clines and their significance. Annals of Botany, 22, 457-477.

ORsI, s. 1963. Il ginestrino e la produzione del seme. Sementi Elette, 3, 916-206.

роОт⿻сні, I. 1959. Agronomic, genetic and cytological investigation on vigor of establishment, growth form and other morphological characters in birdsfoot trefoil Lotus corniculatus L. Ph.D. Thesis, Cornell University, U.S.A.

PRIME, C. T. 1955. Variation Arrum maculatum. Watsonia, 3, 181-185.

Robinson, D. H. 1947. Leguminous Forage Crops. 2nd Edition. Edward Arnold.

SEAney, R. R., And henson, P. R. 1970. Birdsfoot trefoil. Adv. Agronomy, 22, 119-157. 
SOMAROO, B. H., AND GRANT W. F. 1972. Meiotic chromosome behaviour in tetraploid hybrids between synthetic Lotus amphidiploids and $L$. corniculatus. Canad. F. Genet. Cylol., 14, 57-64.

TUtin, T. G., HEYWOOD, V. H., BURGes, N. W., MOORE, D. M., VAlentine, D. H., WALTERS, s. M., AND WEBB, D. A. 1968. Eds. Flora Europea, Volume 2. Cambridge University Press.

URBANSKA-WORYTKIEWICZ, K., AND WILDI, O. 1975. Variation within Lotus corniculatus L. sensu lato from Switzerland. I. Preliminary report on chromosome numbers and cyanogenesis. Berichte de Geobot. Inst. Züirich, 43, 54-82.

usher, м. в. 1975. Analysis of pattern in real and artificial plant populations. 7. Ecol., 63, 569-586.

DE WAAL, D. 1942. Het cyanophore karakter van Witte Klaver, (Trifolium repens L.). $\mathrm{Ph}$.D. Thesis, Landbouwhoogeschool, Wageningen.

Wernsman, E. A., KEIM, W. F., AND DAvis, R. L. 1964. Meiotic behaviour in two Lotus species. Crop Science, 4, 483-486.

yates, F. 1971. Sampling Methods for Censuses and Surveys, 3rd Edition. Griffin, London.

ZITNAK, A. 1973. Assay methods for hydrocyanic acid in plant tissues and their application in studies of cyanogenetic glycosides in Manihot esculenta. In Chronic Cassava Toxicity, ed. B. Nestel and R. MacIntyre, pp. 88-96. International Development Research Centre, Canada. 